\title{
Kompetensi Dakwah Dan Praktek Safari Romadlon Santri Darussalam Sumbersari Kencong Kepung Kediri.
}

\author{
Rohmad \\ Pascasarjana Institut Agama Islam Tribakti Kediri \\ rohmad@gmail.com
}

\begin{abstract}
This study concerns the competence of da'wah and Romadlon safari practices which are specifically directed at santri in the Islamic Boarding School of Sumbersari Kencong Kepung, Kediri Regency relating to the plunge of students studying in the community for nasyrul ilmi waddin related to da'wah which is manifested in the form of safari Romadlon. This type of research approach is qualitative phenomenological, with a case study design. Data collection is done by in-depth interview techniques, observation, and study documentation. While the data analysis technique, researchers used an interactive analysis model that contained four interrelated components, namely: data collection, data simplification, data exposure, withdrawal and submission of conclusions. Finally, this study managed to obtain findings in accordance with the problem questions which in general can be concluded as follows: 1). Da'wah planning implemented at Darussalam Sumbersari Islamic boarding school in general can be said to be good which includes training, screening of all Romadlon safari participants so that safari activities can go well, 2). Romadlon safari practices by recording areas that will be occupied by the students went well, 3). Santri who was deployed assisted by the Romadlon safari committee was felt to be able to overcome the existing problems both internally and externally.
\end{abstract}

Keywords: Da'wah Competence, Safari Ramadhan

\begin{abstract}
Abstrak
Penelitian ini menyangkut kompetensi dakwah dan praktek safari Romadlon yang secara khusus diarahkan pada santri di Pondok Pesantren Darussalam Sumbersari Kencong Kepung Kabupaten Kediri yang berkaitan dengan terjunnya para santri belajar di masyarakat untuk nasyrul ilmi waddin berkaitan dengan dakwah yang diwujudkan dengan bentuk safari romadlon. Jenis pendekatan penelitian ini adalah kualitatif fenomenologik, dengan rancangan studi kasus. Pengumpulan data dilakukan dengan teknik wawancara mendalam, observasi, dan studi dokumentasi. Sedangkan teknik analisa data, peneliti menggunakan model analisis interaktif yang mengandung empat komponen yang saling berkaitan, yaitu: pengumpulan data, penyederhanaan data, pemaparan data, penarikan dan pengajuan simpulan. Akhirnya, penelitian ini berhasil memperoleh temuan sesuai pertanyaan permasalahan yang pada garis besarnya dapat disimpulkan sebagai berikut: 1). Perencanaan
\end{abstract}


dakwah yang diterapkan di pondok pesantren Darussalam Sumbersari secara umum sudah bisa dikatakan baik yang meliputi pelatihan,penyaringan semua peserta safari Romadlon sehingga kegiatan safari bisa berjalan dengan baik, 2). Praktek safari Romadlon dengan mendata daerah-daerah yang akan diterjuni para santri berjalan dengan baik, 3). Santri yang diterjunkan dibantu dengan panitia safari Romadlon dirasa sudah bisa mengatasi problem yang ada baik secara internal maupun secara eksternal.

Kata Kunci: Konpetensi Dakwah, Safari Ramadhan

\section{Pendahuluan}

Salah satu unsur yang sangat penting dan menunjang keberhasilan seorang santri adalah pelatihan dakwah, karena Islam adalah agama yang mengajarkan kepada pemeluknya untuk menyampaikan ajaran Islam ditengahtengah masyarakat. Dakwah adalah suatu kewajiban yang harus dilaksanakan oleh umat Islam dalam kenyataan hidup sehari-hari disegala aspek kehidupan manusia. Sebab bagaimanapun baiknya ideology (agama) yang harus disebar luaskan kepada masyarakat,agama akan tetap sebagai cita-cita yang tidak akan terwujud jika tidak ada manusia yang menyebarluaskan. Oleh karena itu perlu adanya tenaga pelaksana dakwah yang cukup serta ikhlas melaksanakannya.

Perlu kita sadari perjuangan Islam masih panjang dan lama bahkan tidak ada habis-habisnya selagi dunia dan manusia ini masih ada. Padahal usia para juru dakwah yang sekarang ini makin hari makin tua dan satu persatu meninggalkan kita. Sementara sekarang ini banyak keluhan masyarakat tentang kurangnya juru dakwah. Karena itu berkeliling dari desa ke desa, yang dikenal dengan nama Safari Ramadan.

Dakwah yang berupa kegiatan Safari Romadlon bagi santri sangat penting yaitu sebagai usaha kelangsungan dakwah Islamiyah juga sebagai usaha pemerataan dan menyebar luaskan dakwah kedaerah-daerah yang belum tersentuh. Oleh karena itu untuk menyebarluaskan agama Islam butuh santri-santri yang mampu untuk berdakwah.

Terhadap permasalahan tersebut diatas pondok pesantren sebagai salah satu lembaga pendidikan Islam,kiranya sangat baik menumbuhkembangkan kader-kader da'i, sebagaimana kita ketahui bahwa pondok pesantren merupakan tempat untuk mempelajari dan memperdalam ilmu agama Islam. Di samping itu dalam kenyataannya pondok pesantren cukup banyak mencetak kaderkader umat dan berkepribadian muslim, berilmu dan beramal. Dengan demikian orang-orang yang ada dipondok pesantren memungkinkan sekali untuk mengembangkan agama Islam di masyarakat.

Pondok pesantren Darussalam Sumbersari Kencong Kepung Kediri ikut pula berpartisipasi dalam menyiapkan 
juru dakwah bahkan sudah ratusan alumni pondok pesantren Darussalam yang aktif dalam menyebarkan agama Islam di masyarakat melalui bidang kehidupan dan santri yang masih ada di pondok pesantren dilatih berdakwah dengan cara setiap bulan Romadlon diterjunkan di masyarakat yang biasa disebut dengan Safari Romadlon.

Kegiatan dakwah di masyarakat yang berupa Safari Romadlon ini menjadi daya tarik tersendiri dan merupakan alasan bagi wali santri untuk memondokkan anak-anak mereka di pesantren. Bagi mereka, Safari Romadlon merupakan pembelajaran yang sangat sesuai untuk langkah anak mereka dalam menghadapi tantangan zaman, untuk menghadapi masyarakat yang berbagai macam corak, untuk belajar berdakwah ditengah-tengah masayarakat. Artinya, wali santri merasa tertarik memondokkan anak-anak di pesantren bukan sekedar berdasarkan alasan agar anak bisa belajar ilmu agama saja, tetapi lebih dari itu tindakan memondokkan anak dilakukan karena mereka merasa cukup memahami kondisi lembaga pesantren, sehingga timbul kepercayaan terhadap pesantren sebagai tempat yang layak bagi pendidikan anak-anak mereka.

Untuk membentuk peserta didik atau santri menjadi yang beriman dan bertakwa serta berakhlak mulia tidaklah semudah yang dibayangkan serta tidak bisa hanya mengandalkan pada pembelajaran yang ada di pondok pesantren, tetapi butuh pembinaan secara terus menerus serta berkelanjutan di luar jam pelajaran, baik dalam pondok maupun di luar pondok, melalui kegiatan dakwah yang berupa Safari Romadlon.

Selama ini dakwah sudah terkenal dikalangan masyarakat,akan tetapi masih banyak diantara mereka yang belum mengetahui hukumnya. Berkaitan dengan hal ini maka kiranya perlu sekali kami menjelaskan tentang hukum dakwah karena pada dasarnya dakwah adalah meliputi banyak hal.

Dakwah ini diwajibkan bagi setiap insan sesuai dengan kemampuannya masing-masing. Allah telah berfirman :

"Serulah (manusia) kepada jalan Tuhan-mu dengan hikmah dan pelajaran yang baik dan bantahlah mereka dengan cara yang baik. Sesungguhnya Tuhanmu Dialah yang lebih mengetahui tentang siapa yang tersesat dari jalan-Nya dan Dialah yang lebih mengetahui orang-orang yang mendapat petunjuk". ${ }^{1}$

Lembaga pendidikan pondok pesantren ini merupakan lembaga pendidikan dan pengajaran dibawah naungan yayasan Salimiyah Sumbersari Kediri yang notabene Kediri sebagai Kabupaten yang memiliki banyak lembaga pondok pesantren besar yang semestinya tingkat kemampuan berdakwah ini harus lebih baik dari kabupaten/kota lain, Berdasarkan konteks permasalahan di atas, maka penelitian ini mengambil judul "Kompetensi Dakwah dan Praktek Safari Romadlon Santri Darussalam Sumbersari Kencong Kepung Kediri". 


\section{Metode}

Pendekatan penelitian ini menggunakan penelitian kualitatif. Adapun jenis penelitian yang digunakan jenis penelitian studi kasus. Ada beberapa alasan kuat tentang pentingnya penelitian kualitatif dalam pendidikan diantaranya bertujuan; 1) mendiskripsikan suatu proses kegiatan pendidikan berdasarkan apa yang terjadi dilapangan sebagai bahan kajian lebih lanjut untuk menemukan kekurangan dan kelemahan pendidikan sehingga dapat ditentukan upaya penyempurnaannya, 2) menganalisisa dan menafsirkan suatu fakta, gejala dan peristiwa pendidikan yang terjadi dilapangan sebagaimana adanya dalam konteks ruang dan waktu serta situasi lingkungan pendidikan yang alami.

Prosedur pengumpulan data pada penelitian ini adalah observasi, wawancara, dan dokumentasi. Sebab bagi penelitian kualitatif fenomena dapat dimengerti maknanya secara baik, apabila dilakukan interaksi dengan subyek melalui wawancara mendalam dan observasi pada lapangan, dimana fenomena tersebut berlangsung dan disamping itu untuk melengkapi data diperlukan dokumentasi (tentang bahanbahan yang ditulis oleh atau tentang subyek).

Analisis data tersebut dilakukan dalam suatu proses. Proses berarti pelaksanaannya sudah mulai dilakukan sejak pengumpulan data dilakukan dan dikerjakan secara insentif. Dalam $\checkmark$ penelitian ini penulis membagi serta melaksanakan tahap analisis data sebagai berikut :

Pertama display data. Pada tahap ini data dikumpulkan dengan cara dinarasikan dengan berbagai cara baik dari wawancara, interview, dan dokumentasi.

Kedua reduksi data. Pada tahap ini merupakan proses kegiatan yang dilakukan oleh peneliti untuk memilih, menyederhanakan, mengabstraksi sekaligus mentransformasi data lapangan kedalam format yang telah disediakan. Reduksi data serta pemaparan hasilnya dilakukan secara terus menerus ketika proses pengumpulan data berlangsung, selanjutnya dari hasil reduksi data kemudian ditarik kesimpulankesimpulan sementara.

Ketiga Penarikan Kesimpulan. Awal pengumpulan data dilapangan, peneliti dimungkinkan untuk menarik kesimpulan. Pada saat peneliti memberi arti dan memaknai data-data yang diperoleh baik melalui observasi, wawancara maupun studi dokumentasi berarti peneliti telah menarik kesimpulan. Namun kesimpulankesimpulan itu masih bersifat sementara, sebab pada awalnya masih belum jelas dan masih berpeluang untuk berubah menjadi suatu kondisi yang berkembang dilapangan.

\section{Kajian Teori \\ Perencanaan Dakwah}

Perencanaan dalam mengadakan pelatihan safari Romadlon, merupakan proyeksi tentang apa yang diperlukan dalam rangka mencapai tujuan, 
sebagaimana yang disampaikan akhmad sudrajat sebagai berikut:

Perencanaan merupakan proses yang sistematis dalam pengambilam keputusan tentang tindakan yang akan dilakukan pada waktu yang akan datang. Disebut sistematis, karena perencanaan dilaksanakan dengan menggunakan prinsip-prinsip yang mencakup proses pengambilan keputusan, penggunaan pengetahuan, dan teknik secara ilmiyah, serta tindakan atau kegiatan yang terorganisir $^{2}$

Dalam

$$
\text { manajemen }
$$

dakwah, perencanaan merupakan perumusan tentang apa yang akan dicapai dan tindakan apa yang akan dilakukan dalam mencapai tujuan mencetak kader mubaligh yang berwawasan luas. dalam hal ini,maka perencanaan memiliki arti penting. adapun langkah-langkah perencanaan menurut Abdul Rosyad Shaleh adalah sebagai berikut :

\section{Perkiraan dan perhitungan masa} depan (Forecasting)

Forecasting adalah tindakan memperkirakan dan memperhitungkan segala kemungkinan dan kejadian yang mungkin timbul dan dihadapi di masa depan berdasarkan hasil analisa terhadap data dan keterangan-keterangan yang kongkrit. ${ }^{3}$ perencanaan dakwah di masa datang memerlukan perkiraan dan perhitungan yang cermat sebab masa datang adalah suatu prakondisi yang belum dikenal dan penuh ketidakpastian yang selalu berubah-rubah.

2. Penentuan dan perumusan sasaran dalam rangka pencapaian tujuan dakwah yang telah ditetapkan sebelumnya.

Penyelenggaraan dakwah dalam rangka pencapaian tujuan,dirangkai ke dalam beberapa kegiatan melalui tahapan-tahapan dalam periode tertentu. penetapan tujuan ini merupakan langkah kedua sesudah Forecasting. Hal ini menjadi penting,sebab gerak langkah suatu kegiatan akan diarahkan kepada tujuan. Oleh karena itu,ia merupakan suatu keadaan yang harus menjadi acuan pada setiap pelaksanaan dakwah.

Tujuan tersebut harus diarahkan pada sasaran dakwah yang telah dirumuskan secara pasti dan menjadi arah bagi segenap tindakan yang dilakukan pimpinan. Tujuan tersebut diwujudkan dalam bentuk target atau sasaran kongkrit yang diharapkan dapat dicapai. ${ }^{4}$ Sasaran dakwah tersebut harus diperjelas secara gamblang guna mengetahui kondisi sasaran yang diharapkan,wujud sasaran tersebut berbentuk individu maupun komunitas masyarakat. ${ }^{5}$

\section{Penempatan lokasi}

Penentuan lokasi yang tepat,turut mempengaruhi kualitas tindakan dakwah. Oleh karena itu,lokasi harus
2 Sudjana, Menejemen Program Pendidikan untuk pendidikan luar sekolah dan pengembangan sumberdaya manusia, ( Bandung: Falah Production,2000). Hal 61 3 ibid. hlm 65
${ }^{4}$ Zaini Muchtarom,Dasar-Dasar Manajemen Dakwah, (Yogyakarta, Amin Press,1996). hlm 4142

5 Didin Hafidhuddin, Dakwah Aktual, (Jakarta: Gema Insani Press,2001) hlm 184-185 
dilihat dari segi fungsionalnya dari segi untung ruginya,sebab lokasi sangat terkait dengan pembiyaan, waktu, tenaga, fasilitas atau perlengkapan yang diperlukan. Untuk itulah lokasi merupakan bagian yang tidak terpisahkan dalam rangka perencanaan dakwah.

4. Penetapan biaya

Setiap kegiatan memerlukan biaya kegiatan tanpa ditunjang oleh dana yang memadai, akan turut mempengaruhi pelaksanaan dakwah. Pusat dakwah Islam Indonesia memberikan definisi tentang dana dakwah, yaitu segala tenaga atau modal uang peralatan yang dapat dipergunakan dalam kegiatan dakwah. Batasan tersebut meliputi segala perbendaharaan yang bernilai material yang dapat dimanfaatkan sebagai sarana dalam pelaksanaan dakwah.

Perencanaan juga akan mempermudah pengurus pondok pesantren untuk melaksanakan pengawasan dan penilaian terhadap jalannya aktifitas dakwah,dalam hal ini adalah kegiatan Tarbiyatul Mubalighin. Jadi perencanaan merupakan fungsi manajemen yang mempunyai peran penting dalam setiap pelaksanaan suatu program kegiatan seperti halnya kegiatan Tarbiyatul Mubalighin dalam membentuk kader mubaligh yang berwawasan luas.

Dalam proses perencanaan pada umumnya mencakup beberapa tahap, sebagaimana yang dikemukakan oleh Chesswas yang mengatakan bahwa proses perencanaan itu terdiri dari menilai kebutuhan pendidikan, merumuskan tujuan pendidikan, merumuskan kebijakan, merumuskan program, menguji kelayakan, menerap-kan rencana, dan menilai merevisi untuk rencana yang akan datang 6

\section{Kompetensi Dakwah}

Ada beberapa pengertina tentang Kompetensi Dakwa, di antaranya pendapat Hamzah Ya'qub mengatakan bahwa dakwah adalah mengajak umat manusia dengan hikmah (kebijaksanaan) untuk mengikuti petunjuk Allah dan Rasul-Nya. Sementara menurut Muhammad Natsir dakwah mengandung arti kewajiban yang menjadi tanggung jawab seorang muslim dalam amar ma'ruf nahi mungkar. ${ }^{7}$

Dari definisi-definisi tersebut, meskipun terdapat perbedaan dalam perumusan, tetapi apabila diperbandingkan satu sama lain,dapatlah diambil kesimpulan sebagai berikut "Dakwah menjadikan prilaku manusia dalam menjalankan Islam sebagai agama Rohmatan Lil Alamin yang harus didakwahkan kepada seluruh manusia, yang dalam prosesnya melibatkan unsur: $D a^{\prime} i$ (Subjek), Maaddah (materi), Thoriqoh (metode), Washilah (media) dan Mad'u (objek) dalam mencapai Maqashid (tujuan) dakwah yang melekat dengan tujuan Islam yaitu mencapai kebahagian hidup didunia dan akhirat.

Menurut definisi di atas bahwa kompetensi dakwah meliputi segala 
kiprah yang berbentuk ucapan atau perbuatan yang mempunyai ruang lingkup luas sekali, berbeda dengan Tabligh yang lebih banyak menitik beratkan kepada penyampaian dengan lisan. Sebagaimana firman Allah kepada nabi Muhammad SAW:

Hai rasul, sampaikanlah apa yang diturunkan kepadamu dari Tuhanmu. dan jika tidak kamu kerjakan (apa yang diperintahkan itu, berarti) kamu tidak menyampaikan amanat-Nya. (al-maidah $: 67)^{8}$

Lain halnya dengan dakwah yang lebih banyak mengarah mengajak bersama-sama,perhatikanlah bahwa Allah menggunakan lafadz dakwah untuk mengajak bersama-sama (antar obyek dan da'inya ). Sebagaimana firman Allah:

Hai kaumku, Bagaimanakah kamu, aku menyeru kamu kepada keselamatan, tetapi kamu menyeru aku ke neraka? (Kenapa) kamu menyeruku supaya kafir kepada Allah dan mempersekutukan-Nya dengan apa yang tidak kuketahui Padahal aku menyeru kamu (beriman) kepada yang Maha Perkasa lagi Maha Pengampun?(Al-Mukminun:41-42)

\section{Safari Romadlon Santri}

pada saat bulan romadlon tiba biasanya ini menjadi jembatan untuk lebih dekat kepada allah swt,serta manfaat bagi masyarakat adalah adanya kedekatan pondok pesantren dengan masyarakat sekitar pondok pesantren atau kedekatan antara masyarakat dengan masyarakat. Yang mana dalam bulan romadlon banyak kegiatan yang bersifat kolektif,misalnya kegiatan berbuka atau sholat tarawih,sehingga dapat mempermudah berkomunikasi secara lebih efektif dan efisien tanpa harus mengumpulkan masyarakat.

Dibulan puasa safari Romadlon adalah sebagai ajang silaturrohim antara sesama muslim dibulan Romadlon. Dimana tradisi silaturrohim ini sangat dianjurkan karena memiliki efek yang sangat konstruktif baik bagi kehidupan individu maupun social. sebagaimana dianjurkan oleh Rosululloh,silaturrohim memiliki banyak manfaat. Diantaranya adalah memperpanjang usia dan memperbanyak rezeki bagi yang melakukannya.

Dengan adanya safari Romadlon ini secara tidak langsung dapat memperkuat persatuan dan kebersamaan baik diantara kalangan masyarakat sendiri maupun antara masyarakat dengan pondok pesantren. Oleh karena itu dengan safari romadlon maka masyarakat yang belum begitu kenal tentang agama akan bisa sepenuhnya tau tentang agama Islam. Karena yang menjadi objek adalah masyarakat yang masih jauh dari sentuhan orang alim.

Safari Romadlon adalah kegiatan yang sudah dicanangkan oleh lembaga Darussalam bagi santri yang sudah mampu untuk berdakwah,dengan tujuan jika santri pulang dimasyarakat nanti sudah siap untuk berjuang.

Ketika kita berpijak dari QS AlNahl ayat 125 yaitu: 
"serulah manusia kepada jalan Tuhanmu dengan hikmah dan pelajaran yang baik dan bantahlah mereka dengan cara yang baik. Sesungguhnya Tuhanmu Dialah yang lebih mengetahui tentang siapa yang tersesat dijalan-Nya dan Dialah yang lebih mengetahui orang-orang yang mendapat petunjuk".

Dari ayat tersebut dapat diambil pemahaman bahwa metode dakwah itu meliputi tiga cakupan,yaitu:

Pertama, bil hikmah, artinya hikmah dalam dunia dakwah mempunyai posisi yang sangat penting yaitu dapat menentukan sukses dan tidaknya dakwah. Dalam menghadapi Mad'u yang beragam tingkat pendidikan, strata social dan latar belakang budaya, para da'i memerlukan hikmah,sehingga ajaran Islam mampu memasuki ruang hati para Mad'u dengan tepat. Oleh karena itu para da'i dituntut untuk mampu mengerti dan memahami sekaligus memanfaatkan latar belakangnya, sehingga ide-ide yang dterima dirasakan sebagai sesuatu yang menyentuh dan menyejukkan kalbunya.

Pada suatu saat boleh jadi diamnya da'i menjadi efektif dan berbicara membawa bencana,tetapi disaat lain terjadi sebaliknya diam malah mendatangkan bahaya besar dan berbicara mendatangkan hasil yang gemilang. Kemampuan da'i menempatkan dirinya, kapan harus berbicara kapan harus memilih diam juga termasuk bagian dari hikmah dalam berdakwah.

Da'i tidak boleh hanya sekedar menyampaikan ajaran agama tanpa mengamalkannya. Seharusnya da'ilah orang pertama yang mengamalkan apa yang diucapkannya. Kemampuan da'i untuk menjadi contoh nyata umatnya dalam bertindak adalah hikmah yang seharusnya tidak boleh ditinggalkan oleh seorang da'i. Dengan amalan nyata yang langsung dilihat oleh masyarakatnya, para da'i tidak terlalu sulit untuk harus berbicara banyak, tetapi gerak dia adalah dakwah yang jauh lebih efektif dari sekedar berbicara.

Kedua, Bil mauidhotil hasanah, merupakan salah satu metode dalam dakwah untuk mengajak kejalan Allah dengan memberikan nasehat atau membimbing dengan lemah lembut agar mereka mau berbuat baik.

Menurut Imam Abdulloh bin Ahmad An-Nasafi yang dikutip oleh $\mathrm{H}$. Hasanuddin adalah sebagai berikut: Mauidhotul Hasanah adalah perkataanperkataan yang tidak tersembunyi bagi mereka, bahwa engkau memberikan nasehat dan menghendaki manfaat kepada mereka atau dengan al Qur'an. ${ }^{9}$

Ketiga, Bil mujadalah, adalah upaya tukar pendapat yang dilakukan oleh dua pihak secara sinergis,tanpa adanya suasana yang mengharuskan lahirnya permusuhan diantara keduanya.

Sedangkan menurut Dr. Sayyid Muhammad Thantawi adalah suatu upaya yang bertujuan untuk mengalahkan pendapat lawan dengan cara menyajikan argumentasi dan bukti yang kuat. ${ }^{10}$

10 Sayyid Muhammad Thantawi,Adab alkhiwar fil Islam (Jakarta:azan 2001) hal 38 
Dari pengertian di atas dapat diambil kesimpulan bahwa mujadalah merupakan tukar pendapat yang dilakukan oleh dua pihak secara sinergis, yang tidak melahirkan permusuhan dengan tujuan agar lawan menerima pendapat yang diajukan dengan memberikan argumentasi dan bukti yang kuat. Antara satu dengan lainnya saling menghargai dan menghormati pendapat keduanya berpegang kepada kebenaran, mengakui kebenaran pihak lain dan ikhlas menerima hukuman kebenaran tersebut.

Penelitian Terdahulu Dalam proses penulusuran karya-karya ilmiah yang sama atau mirip dengan penyusunan karya ilmiah ini, maka penulis menelusuri untuk mencari celah dari beberapa kerangka karya ilmiah diantaranya sebagai berikut:

Nur ali "Teori dakwah di pondok pesantren Darul Hikmah Sumbergirang Jamberejo Kedungadem Bojonegoro", pada Tahun 2004. Berdasarkan judul penelitian terdahulu telah dilakukan oleh saudara Nur Ali dengan terdapat beberapa perbedaan dengan judul penelitian yang akan diangkat penulis yakni mengenai "Kompetensi Dakwah Dan Praktek Safari Romadlon Santri Darussalam Sumbersari Kencong Kepung Kediri. Adapun perbedaan tersebut terletak pada beberapa aspek yakni sebagai berikut: pertama terletak pada letak objek penelitian yang berbeda diantara keduanya. Kedua topik utama pembahasan dari keduanya sangat berbeda, apabila pada penelitian milik saudara Nur Ali lebih menekankan kepada pembahasan tentang teori dakwah pondok pesantren. Selanjutnya pada penelitian yang akan diangkat penulis lebih menekankan pada pembahasan mengenai praktek dari teori yang ada dipesantren yaitu melalui kegiatan yang berupa Safari Romadlon. Kemudian selain terdapat perbedaan juga terdapat sedikit persamaan antara penelitian sebelumnya dengan penelitian berikutnya yakni terletak pada aspek : pertama letak persamaan antara keduanya terletak pada objek penelitian yakni sama-sama meneliti pondok pesantren. Kedua sama-sama ada pembahasan tentang teori dakwah.

\section{Hasil dan Pembahasan}

Sebagaimana fokus penelitian yang dibidik pertama, adalah perencanaan dakwah (safari romadlon). Di sini dapat digambarkan bahwa dalam proses perencanaan pada umumnya mencakup beberapa tahap, sebagaimana yang dikemukakan oleh Chesswas yang mengatakan bahwa proses perencanaan itu terdiri dari menilai kebutuhan pendidikan, merumuskan tujuan pendidikan, merumuskan kebijakan, merumuskan program, menguji kelayakan, menerapkan rencana, dan menilai merevisi untuk rencana yang akan datang ${ }^{11}$ 
Berasarkan hasil penelitian, peneliti menemukan bahwa perencanaan dalam mensukseskan kegiatan safari romadlon santri pondok pesantren Darussalam sumbersari, meliputi beberapa hal yaitu mengadakan pelatihan safari Romadlon setiap malam selasa, menjadikan kegiatan safari Romadlon sebagai persyaratan untuk mengikuti ujian, membuat peraturan berupa kode etik, komunikasi dengan anggota safari Romadlon.

Pengelola Pendidikan dakwah dan panitia safari Romadlon merupakan lembaga yang terstruktur dibawah naungan pengasuh pondok pesantren Darussalam, berfungsi sebagai ujung tombak dalam mensukseskan kegiatan safari Romadlon santri pondok, karena secara tidak langsung pengelola pendidikan dakwah dan panitia safari Romadlon adalah pemimpin yang bertanggungjawab atas jalannya proses kegiatan safari Romadlon santri pondok pesantren.

Dalam memimpin kegiatan safari Romadlon santri pondok pesantren, banyak hal yang dilakukan oleh anggota panitia agar jalannya kegiatan safari Romadlon santri pondok pesantren menjadi tertib, sukses sesuai tujuan yang ingin dicapai. Antara lain berkomunikasi kepada santri dalam memberikan pemahaman berkenaan dengan kegiatan safari Romadlon santri Darussalam.

Anggota pendidikan dakwah dan panitia safari Romadlon pondok bertanggungjawab atas maju mundurnya kegiatan safari romadlon santri Darussalam, berusaha mencapai tujuan yang diinginkan maka untuk menggerakkan santri agar lebih mudah dalam mengikuti kegiatan safari Romadlon santri Darussalam maka di butuhkan komunikasi yang baik dengan mereka, seperti halnya yang disampaikan oleh Bpk. Ridloul ghofur sebagai berikut: Komunikasi yang dilakukan oleh anggota pendidikan dakwah dan panitia safari Romadlon dalam menggerakkan para santri merupakan hal yang sangat penting, komunikasi ini sebagai urat nadi dalam menjalankan kegiatan safari Romadlon santri Darussalam pada bulan Romadlon, karena dengan menggunakan komunikasi ini, sangat memudahkan bagi pengurus pendidikan dakwah dan panitia safari Romadlon dalam menunjuk santri dan memberikan saran-saran, nasehat serta informasi dalam hal pentingnya mengikuti kegiatan safari Romadlon ${ }^{12}$

Kedua, praktek Safari Romadlon. Sudah menjadi tradisi setiap bulan Romadlon,pondok

pesantren

Darussalam selalu menterjunkan santrisantri untuk berdakwah di masyarakat yang membutuhkan. Ini bermula dari wacana kepala pondok ketika melihat daerah-daerah yang dekat dengan pondok pesantren masih minim tentang ajaran Islam,sehingga kepala pondok mempunyai inisiatif menawarkan diri untuk menyebarkan keilmuan tentang 
agama di daerah tersebut dan kegiatan ini disebut dengan safari Romadlon.

Pada awalnya hanya empat daerah yang diterjuni oleh santri Darussalam,lama kelamaan kegiatan ini didengar oleh banyak masyarakat, sehingga banyak daerah yang meminta langsung kepondok yang siap didatangi para santri untuk berdakwah,sesuai wawancara kami dengan bapak Muzakki yang telah berkiprah jauh untuk mengikuti safari Romadlon,beliau mengatakan :

Untuk saat ini kegiatan safari Romadlon jauh lebih baik dari pada yang dulu dan bisa saya katakana sudah enak,karena dulu untuk bekal makan dan lain-lain bawa sendiri tapi untuk saat ini semua kebutuhan santri sudah disiapkan oleh masyarakat dan untuk daerah yang diterjuni sudah ada 20 daerah. ${ }^{13}$

Kegiatan safari Romadlon ini sudah dikenal masyarakat dan sudah sangat dipercaya oleh daerah-daerah yang masih membutuhkan siraman rohani yang masih haus dengan ilmu agama sehingga panitia betul-betul mempersiapkan para santri yang akan diterjunkan karena untuk daerah yang diterjuni bukan hanya daerah Kediri saja tapi bahkan sampai pacitan, blitar dan jawa tengah, persiapan yang dilakukan oleh panitia safari Romadlon antara lain:

\section{a) Pra Kegiatan.}

Sebelum para santri diterjunkan di masyarakat untuk menjalankan kegiatan dakwah yang berupa safari Romadlon, para santri disowankan kepada pengasuh pondok pesantren untuk meminta doa dan motifasi agar santri semakin mantap untuk menjalankan tugas sebagai da'i.

Pengarahan merupakan proses menggerakkan santri agar mau belajar dakwah dengan sendirinya dan penuh kesadaran secara bersama-sama untuk mencapai cita-cita lembaga pesantren dan juga anjuran Nabi untuk selalu berdakwah. Pengarahan oleh pengasuh pondok merupakan hal yang wajib, karena pentingnya, maka pengarahanpengarahan dilaksanakan berkali-kali di awal tahun ajaran, seperti ketika acara Halal Bihalal seluruh santri, pembukaan aktifitas organisasi santri, pertemuan santri baru. Disamping itu pengarahan oleh wali (Mustahiq) Kelas tentang wajibnya berdakwah di masyarakat.

Pengasuh pondok pesantren sebagai pimpinan tertinggi atas jalannya kegiatan safari Romadlon di pondok pensantren Darussalam Sumbersari berusaha memberikan motivasi serta inspirasi kepada seluruh santri akan pentingnya mengikuti kegiatan safari Romadlon di pondok pesantren. Dengan adanya motivasi dari pengasuh pondok pesantren, maka akan mudah bagi panitia safari Romadlon dalam mensukseskan kegiatan safari Romadlon.

b) Pelaksanaan

Panitia safari Romadlon sebelum menterjunkan para santri jauh-jauh hari panitia sudah menghubungi takmir masjid atau tokoh masyarakat untuk meminta klarifikasi tentang kegiatan safari Romadlon, artinya jika takmir 
masjid maupun tokoh masyarakat meminta untuk diterjuni maka panitia safari Romadlon menyiapkan santri untuk diterjunkan di daerah yang meminta tersebut.

Ketika santri sudah berada di daerah yang diterjuni maka tugas utama adalah Nasyrul Ilmi Waddin,dan untuk kegiatan sepenuhnya diserahkan kepada tokoh masyarakat yang berkoordinasi dengan anggota safari Romadlon,tapi tetap harus sesuai dengan kode etik yang sudah dibuat oleh panitia safari Romadlon. Kegiatan yang umum yang biasanya disodorkan oleh takmir Masjid dan tokoh masyarakat adalah menjadi imam sholat lima waktu dan imam sholat tarawih dilanjutkan dengan kultum. Sebagaimana yang diutarakan oleh saudara M. Zainal Arifin santri yang ikut safari Romadlon,yaitu:

Dalam menjalankan kegiatan safari romadlon biasanya para santri disamping menjadi imam sholat lima waktu plus tarawih juga ada kegiatan lain yang berupa pengajian kitab kuning tentang tauhid, akhlaq, fiqh dan tajwid. Kadang-kadang juga ada permintaan untuk membantu mengajar di TPQ, SD ,SMP, SMA. Dan pernah juga disruh membantu di taman kanak-kanak. Untuk waktu kegiatan dikondisikan dengan daerah masing-masing. ${ }^{14}$

c) Mengambil keputusan tentang tindakan pelanggaran kode etik safari Romadlon santri Darussalam.
Dalam pengambilan keputusan untuk santri yang melanggar kode etik yang telah ditetapkan di pondok pesantren Darussalam, pengurus safari Romadlon lebih menekankan kesadaran akan pentingnya mengikuti kode etik yang sudah diputuskan oleh panitia supaya dijalankan ketika santri sudah terjun untuk berdakwah. Agar santri lebih menyadari tentang pentingnya menjalankan kode etik tersebut, kesadaran yang muncul dari hati nurani bukan karena takut atau paksaan, sebagai mana yang disampaikan oleh Bpk. Muhtarom yang mengatakan:

Dalam mengambil kebijakan terhadap pelanggaran kode etik safari Romadlon ini, sesuai denga harapan para Pengasuh Pondok dengan menghindari hukuman fisik yang berlebihan, jadi ketika ditempat safari Romadlon ditegur, diingatkan dan ketika sudah kembali kepondok nanti ada hukuman yang bersifat mendidik, seperti mengafal, membaca Al-Qur'an satu jam, mengerjakan tugas kebersihan, dan lainlain ${ }^{15}$

Pengambilan keputusan terhadap pelanggaran kode etik telah ditetapkan secara tertulis, sehingga ketika terjadi pelanggaran oleh anggota safari Romadlon santri, hukuman yang diberikan sesuai dengan yang ditetapkan dan diketahui oleh para santri sebagai mana yang telah dikatakan oleh $\mathrm{M}$. Muhajir santri dari Bojonegoro sebagai berikut:

15 Ust Muhtarom, wawancara di kantor sekretariat Pondok, pukul 21.00 (Sumbersari 20 Agustus 2018)
14 M. Zainal Arifin, wawancara di kantor Jampus, pukul 21.00 (Sumbersari 25 Agustus 2018) 
Sudah sangat jelas sekali tentang kode etik safari Romadlon di pondok ini, karena kode etik safari Romadlon yang ada di pondok sudah dijelaskan secara langsung ketika pertemuan pelatihan safari Romadlon untuk semua anggota safari Romadlon, sehingga bila saya dihukum karena melakukan pelanggaran kode etik maka saya akan menjalani hukumannya dengan ikhlas, karena hukuman yang diberikan sesuai dengan peraturan yang disampaikan pada pertemuan pelatihan safari Romadlon dan saya punya prinsip semua aturan ini agar nanti ketika saya pulang dan saya bermasyarakat akan tau kode etik yang benar ${ }^{16}$

Ketiga, faktor yang berpengaruh terhadap praktek safari romadlon. Setiap kegiatan maupun program pasti ada factor yang mempengaruhi baik itu sifatnya menghambat maupun yang sifatnya mendukung, dari paparan yang sudah ada bisa dikatakan bahwa factor yang secara internal yang menghambat dari kegiatan safari romadlon adalah ketika santri sudah diberi mandat menjadi delegasi safari romadlon pada akhirnya santri mengundurkan diri sehingga panitia kebingungan untuk mencari ganti yang siap untuk diterjunkan. Disamping itu banyak para santri yang kurang persiapan sehingga ketika santri sudah terjun di masyarakat dia kebingungan bahkan kadang ada yang minta pulang kepondok.

factor yang secara eksternal umumnya adanya ketidak cocokkan pendapat antara tokoh masyarakat satu dengan tokoh masyarakat lainnya, sehingga membuat para santri yang diterjunkan harus berupaya untuk tidak memihak salah satu, karena dari pengalaman para santri yang diterjunkan keluhannya kebanyakan seperti itu dan ini bagi santri pemula yang diterjunkan akan susah untuk menghadapinya sehingga menjadikan santri tidak betah dan pada akhirnya menjadikan kegiatan safari Romadlon tidak kondusif.

Untuk mengatasi hambatanhambatan yang ada baik internal maupun eksternal panitia ternyata sudah mempunyai solusi dengan selalu menyiapkan peserta safari Romadlon cadangan untuk mengganti suatu ketika ada peserta safari Romadlon yang tidak bisa untuk diterjunkan. Untuk menghadapi tokoh masyarakat yang berbeda pendapat akhirnya panitia mengusahakan peserta yang diterjunkan biasanya yang satu sudah pengalaman dan yang satunya baru diterjunkan sehingga untuk yang sudah berpengalaman bisa melatih teman barunya dan bisa menghadapi tokoh yang selalu berbeda pendapat.

\section{Kesimpulan}

Berdasarkan penelitian dalam karya tulis ini dapat disimpulkan bahwa: 1. Perencanaan dakwah santri yang ada di pondok pesantren Darussalam Sumbersari dalam meningkatkan kwalitas kegiatan safari Romadlon sudah sangat baik dan berjalan dengan 
tertib,dengan melihat praktek yang dilakukan oleh panitia safari Romadlon dengan melatih para anggota safari Romadlon,difasilitasi buku dakwah dan selalu ada pantauan terus dari panitia.

2. Praktek safari Romadlon santri pondok pesantren Darussalam adalah dengan mendata daerah-daerah yang minta untuk diterjuni para santri,santri diberi tugas untuk menjadi imam sholat lima waktu sekaligus sebagai penceramah,dan juga misi utama praktek safari Romadlon adalah Nasyrul Ilmi Waddin sesuai dengan dawuhnya pendiri pondok pesantren Darussalam.

3. Faktor yang berpengaruh terhadap kegiatan safari Romadlon secara internal adalah kurangnya keinginan santri di dalam mengikuti kegiatan safari Romadlon sehingga dalam praktek pelatihannya juga kurang ada kesemangatan, bahkan sering sekali para santri yang mengundurkan diri satu hari sebelum pemberangkatan dengan alasan disuruh membantu orang tua di rumah dan alasan ini membuat para pengurus tidak bisa berbuat apa-apa. Factor yang secara eksternal yaitu kurang adanya konfirmasi tokoh masyarakat dengan masyarakatnya sehingga menjadi penghambat bagi santri yang diterjunkan sehingga membuat kegiatan safari kurang mengena dan membuat anggota safari patah semangat.

\section{Daftar Pustaka}

Aziz, Moh. Ali. Ilmu Dakwah, Jakarta: Prenada Media, 2004

------. Ilmu Dakwah. Jakarta. Kencana 2012

Departemen Agama RI, Al-qur'an dan terjemahnya, Surabaya: CV. Jaya Sakti, 1989

Hafidhuddin, Didin. Dakwah Aktual, Jakarta: Gema Insani Press, 2001

------. Hukum Dakwah Jakarta: Pedoman Ilmu Jaya, 1996

Ilaihi, Wahyu. Komunikasi Dakwah, Bandung: Remaja Rosdakarya, 2010

Islahi, Amin Ihsan Serba Serbi Dakwah, Bandung, Pustaka, 1989

Muchtarom, Zaini. Dasar-Dasar Manajemen Dakwah, Yogyakarta, Amin Press, 1996

Natsir, M. Fiqhud Dakwah, Jakarta, Media Dakwah, 2000

Saputra, Wahidin. Pengantar Ilmu dakwah, Jakarta, PT. Raja Grafindo Persada 2011

Sudjana, Menejemen Program Pendidikan untuk pendidikan luar sekolah dan pengembangan sumberdaya manusia, Bandung: Falah Production, 2000

Sugiono, Metode Penelitian Kuantitatif Kualitatif RED Bandung: Alfabeta, 2012

Thantawi, Sayyid Muhammad Adab alkhiwar fil Islam, Jakarta: Azan 2001

Usman, Husaini. Manajemen (Teori, Praktik dan riset Pendidikan) edisi IV Jakarta: Bumi Aksara, 2013 